\title{
Active faults' geometry in the Gulf of Aqaba, southern Dead Sea fault, illuminated by multi beam bathymetric data
}

\author{
AUTHORS: Matthieu Ribot ${ }^{1,4}$, Yann Klinger ${ }^{1}$, Sigurjón Jónsson² ${ }^{2}$ Ulas Avsar ${ }^{3}$, Edwige \\ Pons-Branchu ${ }^{4}$, Rémi Matrau², and Francis L. Mallon² \\ (1) Université de Paris, Institut de physique du globe de Paris, CNRS, Paris, France. \\ (2) King Abdullah University of Science and Technology, Thuwal, Saudi Arabia. \\ (3) Middle East Technical University, Ankara, Turkey. \\ (4) Laboratoire des Sciences du Climat et de l'Environnement, Gif-sur-Yvette, France.
}

Corresponding author: Matthieu Ribot (ribot@ipgp.fr)

\section{Key points}

- High-resolution bathymetry of the Gulf of Aqaba

- Detailed map of a complex fault system including strike-slip and normal faulting

- Rupture length of the main subevent of the Mw 7.3, 1995, Nuweiba earthquake and possible candidate for future earthquakes in the gulf.

\begin{abstract}
Detailed knowledge of fault geometry is important for accurate seismic hazard assessment. The Gulf of Aqaba, which corresponds to the southern termination of the 1200-km-long Dead Sea fault system, remains one of the least known parts of this plate boundary fault, in large part due to its location offshore. Classically, the Gulf of Aqaba has been described as a succession of three pull-apart basins. Here, building on a new multibeam bathymetric survey of the Gulf of Aqaba, we provide details about the geometry of the faults at the bottom of the gulf that controls its morphology. In particular, we identify a $50 \mathrm{~km}$-long fault section that shows evidence of recent activation. We associate this fault section (Aragonese fault) with the main fault section that ruptured during the 1995 magnitude $M_{w} 7.3$ Nuweiba earthquake. In the southern part of the gulf, bathymetry emphasizes the strike-slip nature of the Arnona fault, while dip-slip motion seems to be accommodated mostly by faults located along the eastern edge of the gulf. Considering the simple linear geometry of the Arnona fault and the absence of any large earthquake for several centuries, despite an average slip-rate of $\sim 5 \mathrm{~mm} / \mathrm{yr}$, this
\end{abstract}

This article has been accepted for publication and undergone full peer review but has not been through the copyediting, typesetting, pagination and proofreading process, which may lead to differences between this version and the Version of Record. Please cite this article as doi: 10.1029/2020TC006443.

This article is protected by copyright. All rights reserved. 
fault should be considered as a significant candidate for an earthquake rupture of magnitude 7 or above in the near future.

Keywords: Gulf of Aqaba; Dead Sea fault; Bathymetry; Strike-slip fault; Earthquake

\section{Introduction}

The Dead Sea Fault (DSF) is a left-lateral strike-slip fault separating the Arabian plate from the Sinai micro-plate (Figure 1A). Along its southern section, between Lebanon and the Gulf of Aqaba, the slip rate has been extensively studied at different time scales. Although the earthquake activity does not appear to be regular through time (Marco et al., 1996; Lefevre et al., 2018; Wechsler et al., 2018), a slip rate of $5 \pm 1 \mathrm{~mm} / \mathrm{yr}$ agrees well with geodetic data at decadal scale (Reilinger et al., 2006; Le Béon et al., 2008; Al Tarazi et al., 2011), as with rate determinations averaged over the Holocene (Klinger et al., 2000; Le Béon et al., 2010), or even over the entire Quaternary period (Le Béon et al., 2012).

The 180-km-long southern stretch of the fault system is located offshore the cities of Aqaba and Eilat (Figure 1B). There, the fault system forms the Gulf of Aqaba (GA), before the fault goes through the Strait of Tiran (ST) to connect to the Red Sea extensional system (Courtillot et al., 1987). The first bathymetric survey of the GA, which included seismic reflection profiles, was completed in the early 70's. It revealed that the GA is formed by a succession of pull-apart basins (Ben-Avraham et al., 1979). The limited resolution of this survey, however, hampered deciphering any further details of the fault geometry inside the GA. Since then, due to the peculiar geopolitical situation of the GA, which waters are shared by four different countries, only very localized additional geophysical marine data have been acquired (Ehrhardt et al., 2005; Sade et al., 2009; Tibor et al., 2010), which did not provide a general view of the detailed structure of the GA. Indeed, the GA has been the most seismically active part of the DSF during the last century, with the $\mathrm{M}_{\mathrm{w}} 7.3$ Nuweiba earthquake in 1995 (AbdelFattah et al., 1997; Pinar and Türkelli, 1997; Klinger et al., 1999; Shamir et al., 2003; Frucht et al., 2019) that severely affected the coastal city of Nuweiba in Egypt, triggered a small tsunami that swept beaches in Eilat and Aqaba (Frucht et al., 2019), and was also strongly felt in different cities along the Saudi coast. Beside this major event, several significant earthquake swarms have affected the GA during the instrumental period, in 1983, in 1990, and in 1993, that included events with magnitudes as large as $\mathbf{M}_{\mathrm{w}} 6.1$, in addition to a sustained background seismicity (El-Isa et al., 1984; Hussein and Abou Elenean, 2008; Ambraseys, 2009; Al-Arifi et al., 2012; Almadani, 2017; Mostafa et al., 2018). Several large

This article is protected by copyright. All rights reserved. 
historical and prehistorical earthquakes have also been documented that likely occurred in the GA and along the on-shore DSF sections farther North (Shaked et al., 2004; Thomas et al., 2007; Ambraseys, 2009; Klinger et al., 2015; Lefevre et al., 2018)

Here, combining a new multibeam bathymetric dataset acquired in 2018 in the Saudi waters with preexisting data, we establish a detailed map of the active tectonic structures in the GA. Based on the submarine morphology of the active fans, analysis of slope variations, and the mapping of markers of the tectonic deformation involved with the different faults located at the bottom of the GA, we identify the main structure that was most likely activated during the $1995 \mathrm{M}_{\mathrm{w}} 7.3$ Nuweiba earthquake, and we discuss the seismic potential of the other faults located elsewhere in the gulf.

This article is protected by copyright. All rights reserved. 


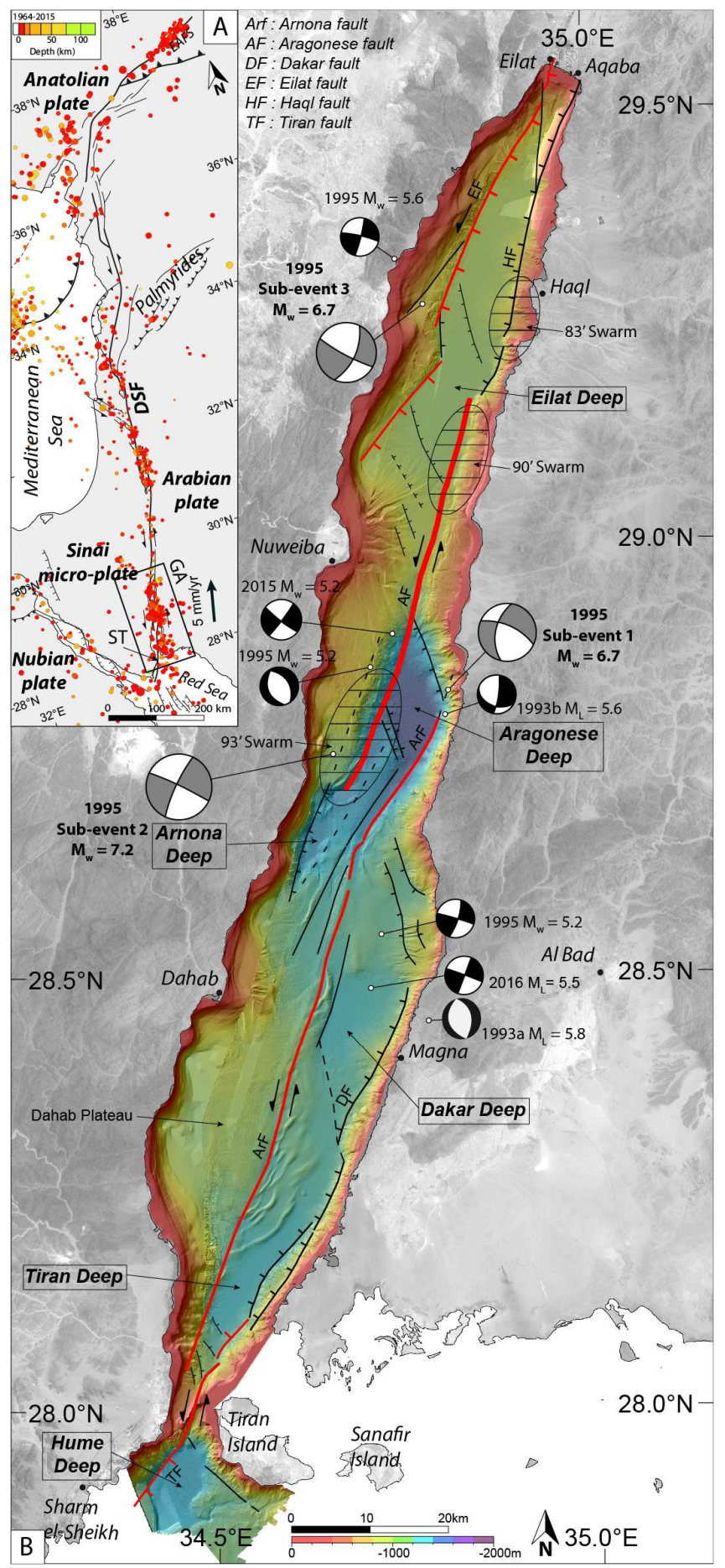

Figure 1: (A) Tectonic setting of the sinistral strike-slip Dead Sea Fault (DSF). Seismicity from the ISC earthquake catalogue 1964 - 2015 (http://www.isc.ac.uk). The DSF connects to the North to the East Anatolian Fault System (EAFS) and to the South to the Red Sea ridge (modified from Le Béon et al., (2008)) GA: Gulf of Aqaba, ST: Strait of Tiran. (B) Multibeam bathymetric map of GA and ST with the main active faults, combining R/V 
Thuwal (2018), F/S Meteor (1999) and Hall \& Ben Avraham (1978) datasets. The main strike-slip faults are in red while normal faults are in black. Fault traces have been simplified for clarity. The grey focal mechanisms corresponding to the successive sub-events for the, Mw7.3, 1995 earthquake, and location of the seismic swarms in 1983, 1990, 1993 and other focal mechanisms after Klinger et al., (1999). Grey background is Landsat 8 Imagery, courtesy of the U.S. Geological Survey (2018). ArF: Arnona Fault, AF: Aragonese Fault, DF: Dakar Fault, EF: Eilat Fault, HF: Haql Fault, TF: Tiran Fault.

\section{Materials and Methods}

A high-resolution bathymetric survey of the eastern half of the GA (within Saudi waters) and the ST was conducted on board the R/V Thuwal from May $20^{\text {th }}$ to June $7^{\text {th }}, 2018$. We used a Kongsberg EM710-MK2 multibeam echo sounder (operating in the 70-100 kHz range) calibrated with CTD (Conductivity, Temperature, Depth) profiles. Due to local regulation, no additional sub-surface geophysical data could be collected at that time. In order to maximize the range capability and to reduce interference from multiple returns we used a transmit fan which sequentially divides the signal into three sectors with distinct transmit frequencies and waveforms. We limited the system to a swath of $2000 \mathrm{~m}$ (i.e. $1000 \mathrm{~m}$ swath on each side of the beamer) in order to ensure appropriate beam density as to grid the data in a $10 \mathrm{~m}$ wide pixel raster across the track. Similarly, the survey speed was kept at 5-6 kn $(\sim 10 \mathrm{~km} / \mathrm{h})$ to limit the spacing between successive survey points and to ensure that the maximum pixel width is $10 \mathrm{~m}$ along the track as well. Survey lines were acquired every $\sim 1000 \mathrm{~m}$ in deep water and $500 \mathrm{~m}$ near the shore, to ensure a double coverage of each point in opposite directions. The GA and ST survey was split into 9 distinct areas. We performed 10 CTD casts in order to calibrate the sound velocity profile of the water column for each surveyed area (see supplementary materials). The results were imported into the commercial SiS multibeam software and used to correct the incoming multibeam data. Then, the bathymetric data were automatically screened for obvious outliers and, additionally, we manually identified and removed remaining spurious data points.

From this dataset, we built a Digital Elevation Model (DEM) of the bathymetry by averaging raw data values to a $10 \mathrm{~m}$ horizontal grid. We combined this new DEM with pre-existing multibeam data from the western part of the GA (F/S Meteor cruise 44 - 1999, maximum resolution of $30 \mathrm{~m}$ (Sade et al., 2009)) to cover $\sim 70 \%$ of the gulf. The remaining gaps were filled using a lower resolution ( $\sim 50 \mathrm{~m}$ ) dataset produced from older ship track surveys (Hall and Ben Avraham, 1978). The contour lines of the bathymetric chart of the Gulf of Eilat were

This article is protected by copyright. All rights reserved. 
digitized and then resampled using a linear interpolation algorithm to get a regular horizontal posting at 50 meters. In addition to the bathymetric DEM (Figure 2A), using the GDAL free software we computed shaded bathymetry and slope maps (Figure 2B \& 2C) to help mapping the different active tectonic structures. The shaded bathymetries were calculated depending on the observed structure with an azimuth of N315 or N135 and with a low-angle altitude of the light source of $25^{\circ}$. The vertical resolution of the DEM is controlled by the pulse duration of the acoustic signal. The vertical resolution $(\mathrm{R})$ can be calculated following $\mathrm{R}$ $=\mathrm{v} \cdot \mathrm{d} / 2$ with $\mathrm{v}$ the wave propagation velocity in water and $\mathrm{d}$ the duration of the signal. During the data acquisition, we tuned the pulse duration at $2 \mathrm{~ms}$, and calibrated the wave propagation velocity with the CTD casts with values ranging between 1535 and $1558 \mathrm{~m} / \mathrm{s}$. Thus, it implies that the vertical resolution is $1.5 \mathrm{~m}$.
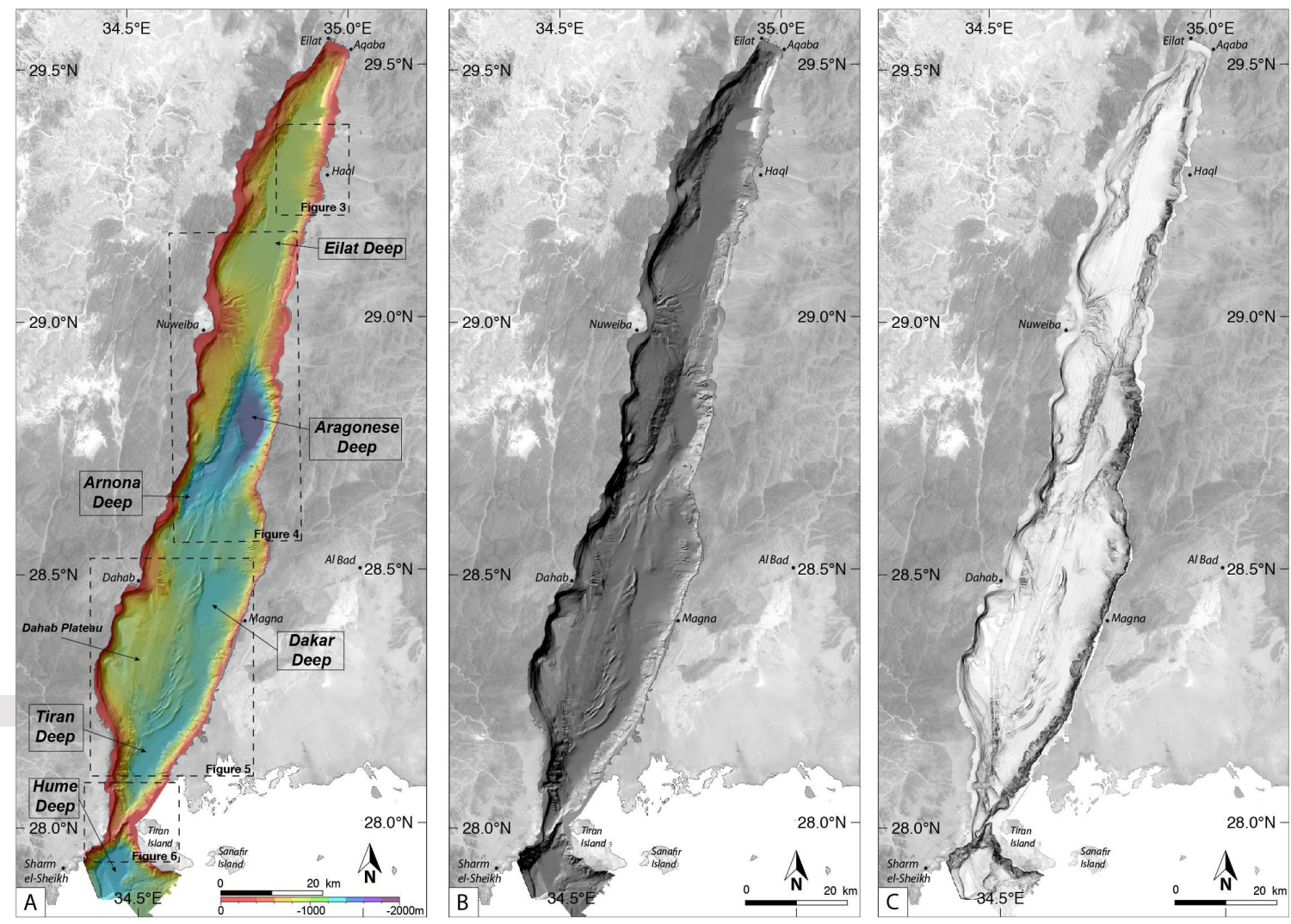

Figure 2: (A) Bathymetric map of the Gulf of Aqaba combining R/V Thuwal (2018), F/S Meteor (1999) and Hall \& Ben Avraham (1978) datasets (B) Shade bathymetry of the Gulf of Aqaba with an azimuth of $315 \mathrm{~N}$ and a sun angle of $25^{\circ}$ (C) Slope map of the Gulf of Aqaba from low slope angle (white: $0^{\circ}$ ) to high slope angle (black: $>45^{\circ}$ ). All maps are projected in

This article is protected by copyright. All rights reserved. 
WGS 84 - UTM 36N. On-land grey background from a Landsat-8 image, courtesy of the U.S. Geological Survey.

\section{Results}

Our new bathymetry confirms that the GA is formed by a succession of pull-apart basins (Figure 1B) (Ben-Avraham et al., 1979; Tibor et al., 2010). The two basins in the northern part of the GA, the Eilat Deep and the Aragonese Deep, are well separated and display a typical pull-apart morphology. Southwest of the Aragonese Deep, near the Egyptian coast, is the smaller Arnona Deep. Further South, the Dakar and the Tiran Deeps, although they are morphologically distinct and separated by a small high, are bounded by a common set of faults; the Arnona strike-slip fault to the West, and the Dakar normal fault to the East. A sixth basin, the Hume Deep, is located in the southernmost section of the Dead Sea fault, South of the Strait of Tiran. From North to South, the Eilat Deep averages to a depth of $900 \mathrm{~m}$, the Aragonese and the Arnona Deeps average at depths of $1750 \mathrm{~m}$ and $1500 \mathrm{~m}$, and the Dakar and the Tiran Deeps average at $1285 \mathrm{~m}$ and $1270 \mathrm{~m}$ depths, respectively. The Hume Deep, that is located outside the proper GA, averages a depth of $1400 \mathrm{~m}$. In fact, the depth of the different basins appears as a reverse image of the high topography surrounding the GA, with mountains reaching $1000 \mathrm{~m}$ and higher only a few kilometers off the eastern and western coasts of the GA. Hence, considering the narrowness of the GA at sea level, which does not exceed about $25 \mathrm{~km}$ at its widest, the GA corresponds to a dramatic topographic change reflecting upon the activity of the Dead Sea fault system. These six basins are interconnected by 3 major leftlateral strike-slip faults, from North to South, the Eilat fault, the Aragonese fault, and the Arnona fault (Figure 1B). In addition to the dominant strike-slip motion, these faults also accommodate some limited amount of normal motion. The average fault azimuth for these three faults are N24, N17 and N20, respectively, similar to the strike-slip direction predicted from the position of the Euler pole between the Sinai micro-plate and the Arabian plate (Le Béon et al., 2008). In addition, each basin is bounded by normal faults. The azimuth of the normal faults in the GA is either clustered around N20 or N160 (Figure 1B). Indeed, the longer normal faults are sub-parallel to the Dead Sea fault direction, which defines the long axis of the GA, about N20. The second set of normal faults, clustered around N160, corresponds to faults oblique to the GA, usually bounding basins to the North and the South. In the northern part of the gulf, the flat-bottom Eilat Deep is bounded by steep slopes. Along its eastern flank, northwest of the city of Haql, large canyons with well-developed submarine fans at their outlet incise through the topographic coastal escarpment formed by the Haql fault

This article is protected by copyright. All rights reserved. 
scarp (Figure 2 and 3). The fault scarp is easily followed at the toe of the topography where one can often find a double scarp with values between $12 \mathrm{~m}$ and $56 \mathrm{~m}$ (see supplementary). We extracted 6 longitudinal profiles across these fans from our bathymetric dataset and projected these profiles with respect to the Haql fault (Figure 3A). The profiles are showing regular undisturbed convex shape and no break-in-slope or knickpoint is visible along the cross-sections, except possibly along the D-D' profile, where a small perturbation is visible (Figure 3B). This profile, however, is taken along the small fan D, onto which less sediments are likely deposited during local storms and could therefore preserve tectonic scarps longer than the larger fans $(\mathrm{B}, \mathrm{E}, \mathrm{F})$. Thus, nowhere the surfaces of the fans $\mathrm{A}, \mathrm{B}, \mathrm{C}, \mathrm{F}$ appear to have been disrupted by any recent fault activity, but at the southern end of the fault escarpment (Figure 3D) where a clear scarp is visible in the shaded topography and slope map. This scarp crosses about one third of the surface of the fan E before disappearing in the area, which corresponds to the current most active part of the submarine alluvial fan. This specific escarpment might possibly attest of some recent tectonic activity. Alternatively, this scarp might not be that recent and the preservation of the scarp would result from the scarp being protected from the sediment coming down the slope of the fan E by the large levee that is visible upslope from the scarp (Figure 3D). This second possibility would be consistent with the fact that no recent scarp is visible either North or South along that strand. Although the morphology of the scarp indicates that this fault is dominated by normal motion, in a few places the shaded topography suggests that a small amount of strike-slip motion might have also been accommodated by this fault. Accurate quantification of lateral displacement, however, would require data with higher resolution.

This article is protected by copyright. All rights reserved. 


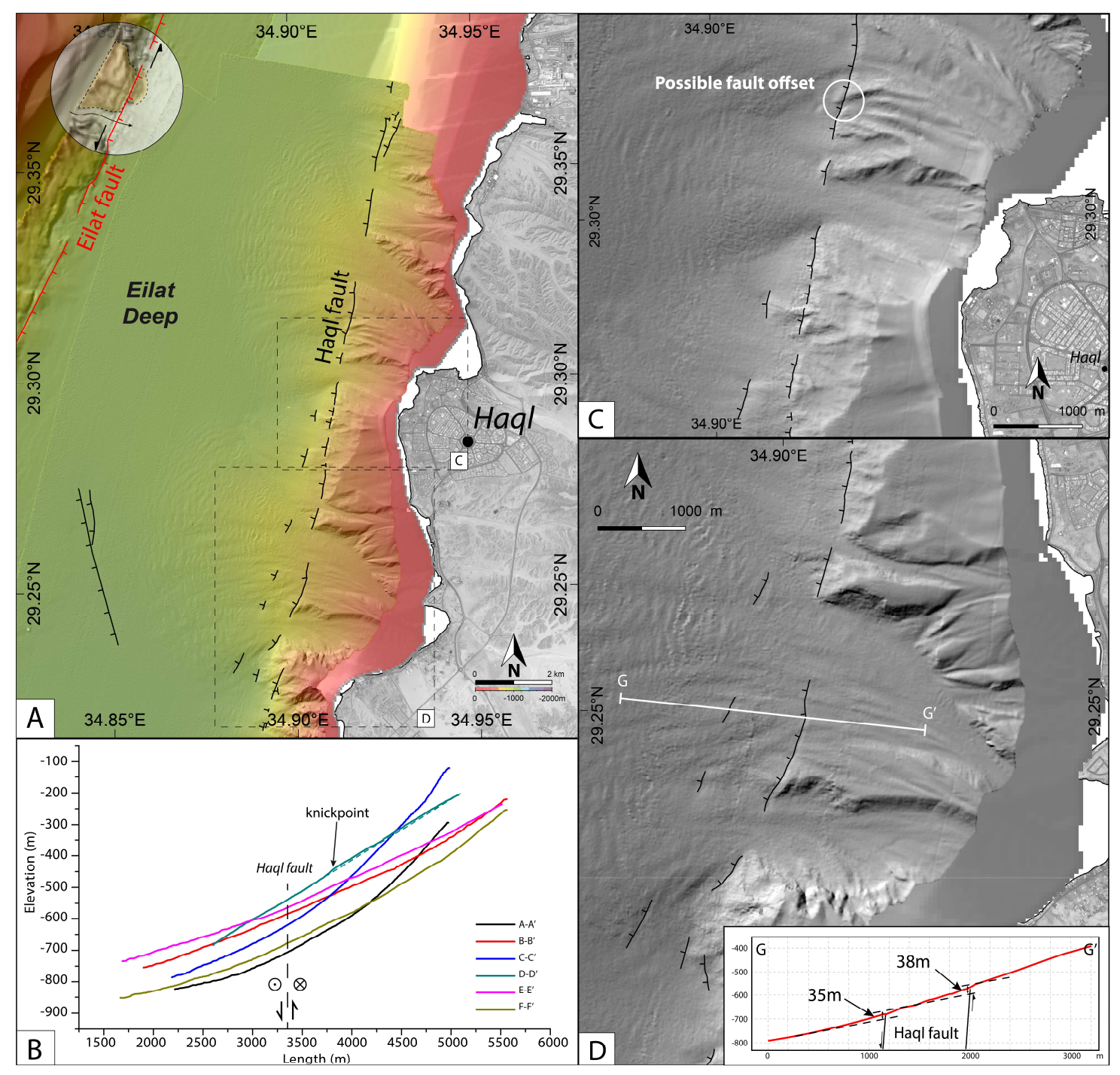

Figure 3: (A) Zoom-in of the northern part of the Gulf of Aqaba, along the morphological trace of the Haql fault (see location on Figure 2) with location of the cross sections shown in (B). The fault lines are more detailed than in Figure 1. Red lines represent the main strike-slip faults, black lines the main normal faults. Along the Eilat fault, a long-term displaced channel as well as the left-lateral displacement of a small hill confirm the strike-slip character of the Eilat fault. (B) Cross-sections along the longitudinal shape of the alluvial fans, North of the city of Haql. No vertical offsets are visible on these cross-sections, with the exception of a possible knickpoint along profile D-D'. The continuous convex shape of the fans suggests no recent activity of the Haql fault. (C) The trace of the Haql fault is buried by fans coming from the coastal plain, with no visible recent perturbations of the fans at this location. Nevertheless, the high relief shows the long-term normal or oblique character of the Haql fault. In few places, the shaded topography suggests that a small part of strike-slip motion is also

This article is protected by copyright. All rights reserved. 
accommodated along the Haql fault. (D) At the southern termination of the Haql fault, discontinuous small scarps across the fans suggest that this section of the fault might have been activated recently.

The western edge of the Eilat Deep is characterized by a set of sub-vertical cliffs going down to the bottom of the basin, as a direct continuation of the steep onshore topography. Unlike along the eastern shore, no wide coastal plain has developed along that part of the GA. Combining bathymetry, shaded bathymetry, and slope map (Figure 2), we could identify two fault sections along that edge of the basin that are connected by a left-stepping normal fault $\left(29.3^{\circ} \mathrm{N} ; 34.8^{\circ} \mathrm{E}\right)$. Despite the lower resolution of the bathymetric data along the western side of the Eilat Deep, in several places one can find evidence for cumulative left-lateral motion (Figure 3A) of $\sim 200 \mathrm{~m}$ to $\sim 300 \mathrm{~m}$ of left-lateral offset. It suggests that a significant part of the horizontal motion accommodated along the Dead Sea fault system is taken up by that strand. The Eilat Deep is bounded both to the North and the South by NW-SE normal faults dipping toward the center of the basin (Ben-Avraham et al., 1979; Ben-Avraham, 1985; Reches, 1987; Ehrhardt et al., 2005; Tibor et al., 2010; Hartman et al., 2014). To the South, however, the faults are buried under sediments from the Nuweiba alluvial fan and could only be recognized owing to slope changes and variations in submarine canyon patterns (Figure 4).

The Aragonese fault connects the Eilat Deep, to the North, to the Aragonese Deep, to the South. This fault is sub-vertical and it accommodates mainly strike-slip motion (BenAvraham et al., 1979). In the North, however, this fault bounds the central part of the Eilat Deep to the East and is slightly dipping westward. Conversely, along its southern section this fault is slightly dipping eastward, as it bounds the Aragonese Deep to the West. This quick change of dip is typical of strike-slip faults in pull-apart configuration (Wu et al., 2009). In addition to the dominant horizontal motion, the Aragonese fault is also accommodating some normal displacement, as part of the pull-apart deformation pattern (Figure 4A). It is worth noting that despite the presence of numerous submarine landslides that affect the footwall of the Aragonese fault in the Aragonese basin (Figure 4A), the fault-scarp morphology remains remarkably well defined at the toe of the slope, attesting of the frequent activity of the fault that keeps refreshing its own scarp. Along the saddle that connects the Eilat Deep to the Aragonese Deeps, the morphology of the fault is characterized by 5 small basins perfectly aligned along the fault strike. Each of these basins is about $100 \mathrm{~m}$ to $150 \mathrm{~m}$ long and $50 \mathrm{~m}$ to $70 \mathrm{~m}$ wide, with a mean depth of $2 \pm 1.3$ meters (Figure 4B). To the South, a counter-slope

This article is protected by copyright. All rights reserved. 
scarp is visible in the bathymetry that marks the transition between the northern and southern part of the Aragonese fault (Figure 4B, B-B').

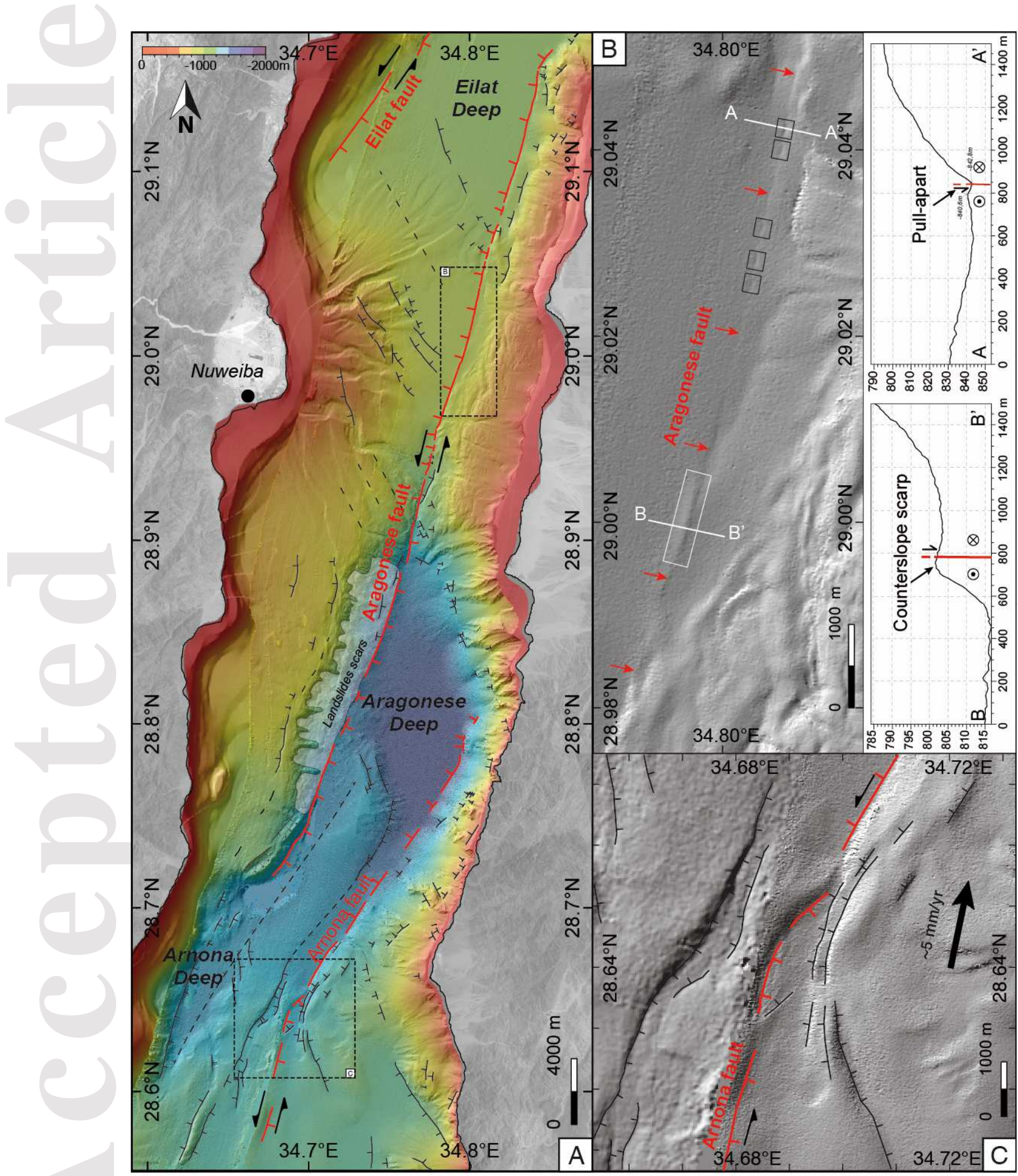

Figure 4: (A) Detailed fault map of the sinistral strike-slip fault system in the central GA. Direct evidence of surface rupture associated to the main subevent (see Fig. 2) of the 1995 
$M w=7.3$ Nuweiba earthquake are found in box B. (B) Sharp fault morphology suggesting very recent fault activation. Small changes of geometry along the Aragonese fault are responsible for small pull-apart (black squares) and counterslope scarp (white square). (C) Detail of the fault zone between Aragonese Deep and Arnona Deep resulting from a complexity in the geometry of the Arnona fault. The red line represents the main active strikeslip fault.

The Aragonese Deep is the deepest depression of the GA, with an average depth of $1750 \mathrm{~m}$ and a maximum depth of $1777 \pm 1.3 \mathrm{~m}$. This basin is narrow, about $5 \mathrm{~km}$ wide at its bottom. The Aragonese and the Arnona strike-slip faults bound the basin respectively to the West and to the East, while its northern and southern sides are bounded by normal faults (e.g. seismic line 26ii in Ben-Avraham, 1985). Those two sets of normal faults are not exposed to similar submarine surface processes. The faults to the north are located along a margin that has a dense canyon network and thus appear to be more discontinuous and largely buried under sediments. Conversely, the southern fault scarps, located at the toe of a submarine topographic high, are linear and well-marked in the morphology. In fact, the difference between the submarine erosional processes affecting the two sides of the basin makes it difficult to assess which side is the more active, holding only on morphology. The fan shape of the sedimentary infill thickening to the south (see seismic line 26ii in Ben-Avraham, 1985) suggests, however, that the southern faults might be currently the most active normal faults in this basin.

Located to the southwest of the Aragonese Deep, at the southern end of the Aragonese fault, the Arnona Deep is a small secondary basin, off the main axis of the GA (Figures $1 \& \mathbf{4}$ ). Short faults with oblique slip bound the basin to the West. Steepness of the coastal slope, however, suggests that dip slip is dominant.

A topographic high $(1394 \pm 1.3 \mathrm{~m}$ depth) separates the Arnona Deep from the Aragonese Deep. It is oriented N35 and bounded on each side by normal faults. It is interpreted as a small horst participating into the left-stepping of the fault system, between the Aragonese and the Arnona fault strands. In addition, the top surface of the topographic high is tilted toward the South due to the dip-slip motion accommodated along the normal faults bounding the Aragonese Deep to the South.

The Dakar and Tiran Deeps are the southernmost basins in the GA (Figure 5). Although the two basins appear as morphologically distinct, the existence of a major structural limit between them remains ambiguous (Ben-Avraham et al., 1979; Ben-Avraham, 1985). Both

This article is protected by copyright. All rights reserved. 
basins are bounded to the East by the Dakar fault. This fault scarp is not very continuous all along the well-developped morphological escarpment, as it is incised in many places by small canyons related to gullies flowing from the large coastal plain. Conspicuous along its southern section, the Dakar fault has a double scarp with unambiguous evidence of vertical motion $(273 \mathrm{~m}$ and $349 \mathrm{~m}$ of cumulative displacement, see supplementary), while no indication of strike-slip motion could be observed. This is consistent with the normal-fault seismic swarm activity that characterizes this section of the GA (e.g., the 1993 earthquake (Hofstetter et al., 2003)).
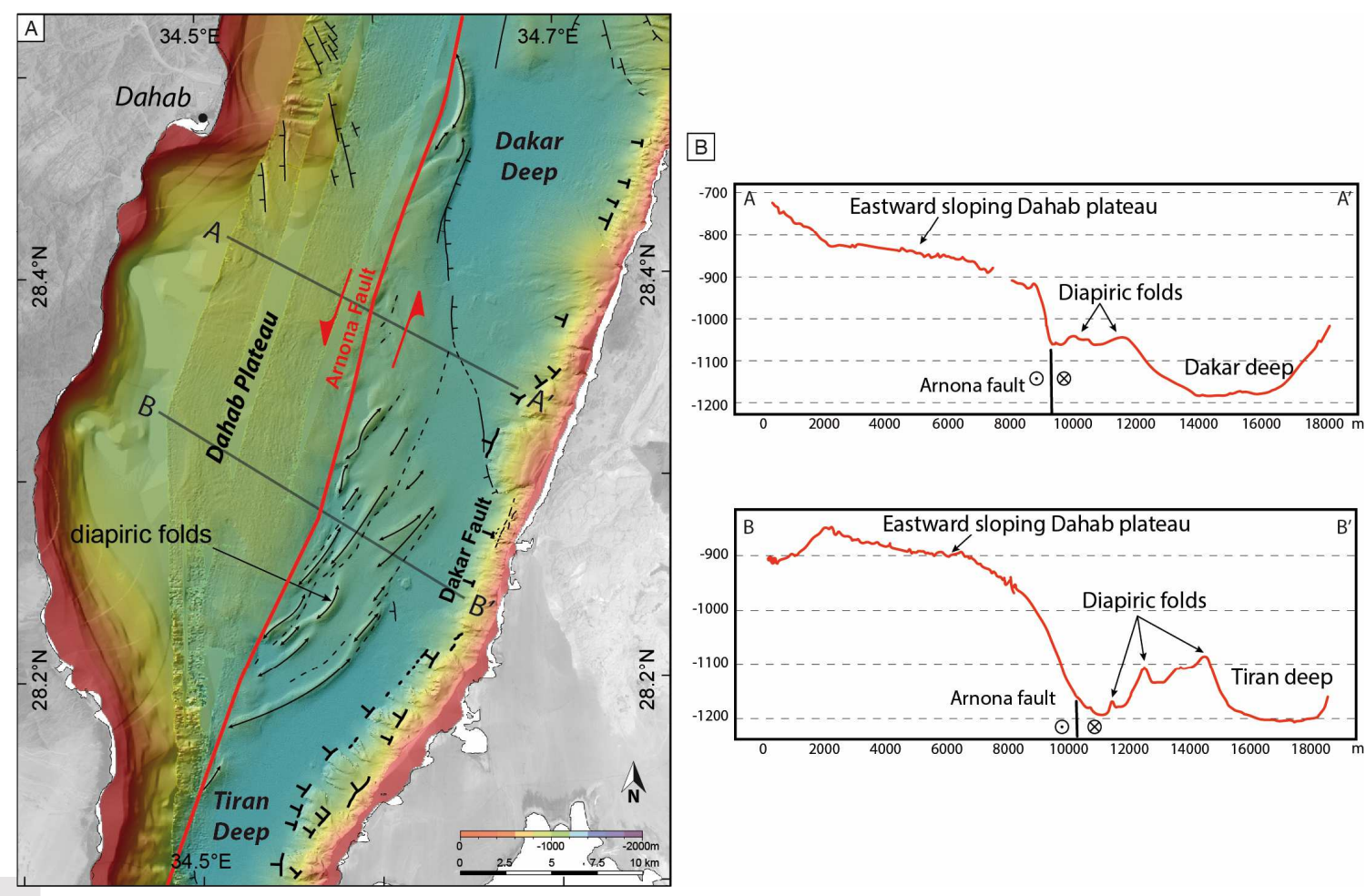

Figure 5: (A) Southern part of the Gulf of Aqaba (see location on Figure 2). Dakar and Tiran Deeps are located between the sinistral strike-slip Arnona fault (red line) and the normal Dakar fault (bold black lines). The location of the main strike-slip fault is partly masked by diapiric foldings (black arrows) and secondary faulting (thin black and dashed black lines) associated with the destabilization of large salt deposits moving down from the Dahab plateau. (B) Cross-sections across the Dahab plateau showing the eastward sloping and the topographic drop from the Dahab plateau toward the Dakar and Tiran deeps.

This article is protected by copyright. All rights reserved. 
To the West, the higher Dahab plateau (mean depth of $900 \mathrm{~m}$ ) can be distinguished from the deeper Dakar and Tiran basins. While the Dahab plateau is characterized by a surface dipping toward the east (Figure 5B and seismic lines in Ben-Avraham et al., 1979), the western edge of the two basins is marked by distinctive diapiric features and cylindrical folds. On average, these folds are about $150 \mathrm{~m}$ high and $600 \mathrm{~m}$ wide. Their length ranges between a couple of kilometers and few tens of kilometers. Most of the fold axis that can be identified in the bathymetry are arcuate in shape, with the southern end pointing towards the SW and the northern end pointing towards the NW. We interpret the topographic drop (Figure 5B) that bounds the Dahab plateau and the basins to correspond to the location of the Arnona fault. The folding seems to be associated with salt diapirs (Ben-Avraham et al., 1979), which origin is likely not tectonic. During the Miocene, post-rift deposits of massive salt layers of the Magna Group are associated with the Red Sea spreading (Tubbs et al., 2014). At that time, the GA was not well defined and thick evaporitic layers covered the entire area. Owing to the DSF activity and the relative motion between Arabia and Sinai, a part of these deposits became isolated in the GA where they sedimented on this plateau. Driven by gravity, the salts layers are now slowly flowing down from the plateau into the two basins, and eventually induce diapirism and folding. Indeed, the apexes of the folds that point eastward (Figure 5) advocates for such triggering mechanism. Alternate mechanism such as folding related to motion along the left-lateral Dead Sea fault seems less likely, as it would involve having fold axis aligned in the direction NE-SW (Fossen et al., 2013), which is not consistent with observation. The Arnona fault morphology itself remains elusive. Beside a lower resolution and only partial data coverage in this area (see supplementary materials for dataset coverage), the less defined fault morphology might also be due to the fact that this section of the fault did not rupture for a long time (see discussion below), unlike the northern section of the GA. Thus, the fault trace is mostly hidden by the hummocky bathymetry related to the folding. Possible secondary faulting, located at the base of the folds, seems to cross-cut the folds and to be syn- to post-formations of the diapiric folds (Figure 5). The southern end of the Tiran Deep is bounded by a series of short parallel normal faults dipping northward (Ben-Avraham, 1985), with well-developed morphology indicating recent activity (Figure 1).

Toward the South, the Strait of Tiran (ST) separates the GA from the northern Red Sea. The ST is constituted of two main channels, the Enterprise passage to the West and the Grafton passage to the East. These channels are separated by four reef islands named, from South to North, the Gordon, Thomas, Woodhouse and Jackson reef. The maximum depth of the shallowest part of the Enterprise and Grafton channels are $255 \pm 1.3 \mathrm{~m}$ and $74 \pm 1.3 \mathrm{~m}$,

This article is protected by copyright. All rights reserved. 
respectively. The elongated shape of the reefs, together with sharp bathymetry, highlight the location of the left-lateral strike-slip Tiran Fault. The Gordon, Thomas, and Woodhouse reefs are located to the West of the fault, while the Jackson reef is located East of the fault (Figure 6). How the Tiran fault connects to strike-slip fault in the Tiran Deep is ambiguous. Most probably it connects to the Arnona strike-slip fault through a small left step jog, while the Dakar Deep accommodates most of the normal motion. To the South, although our current data only provide a limited view, the main strike-slip fault seems to extend westward, bounding the Hume Deep to the North (Figure. 6), to eventually connect to the Red Sea extensional system.

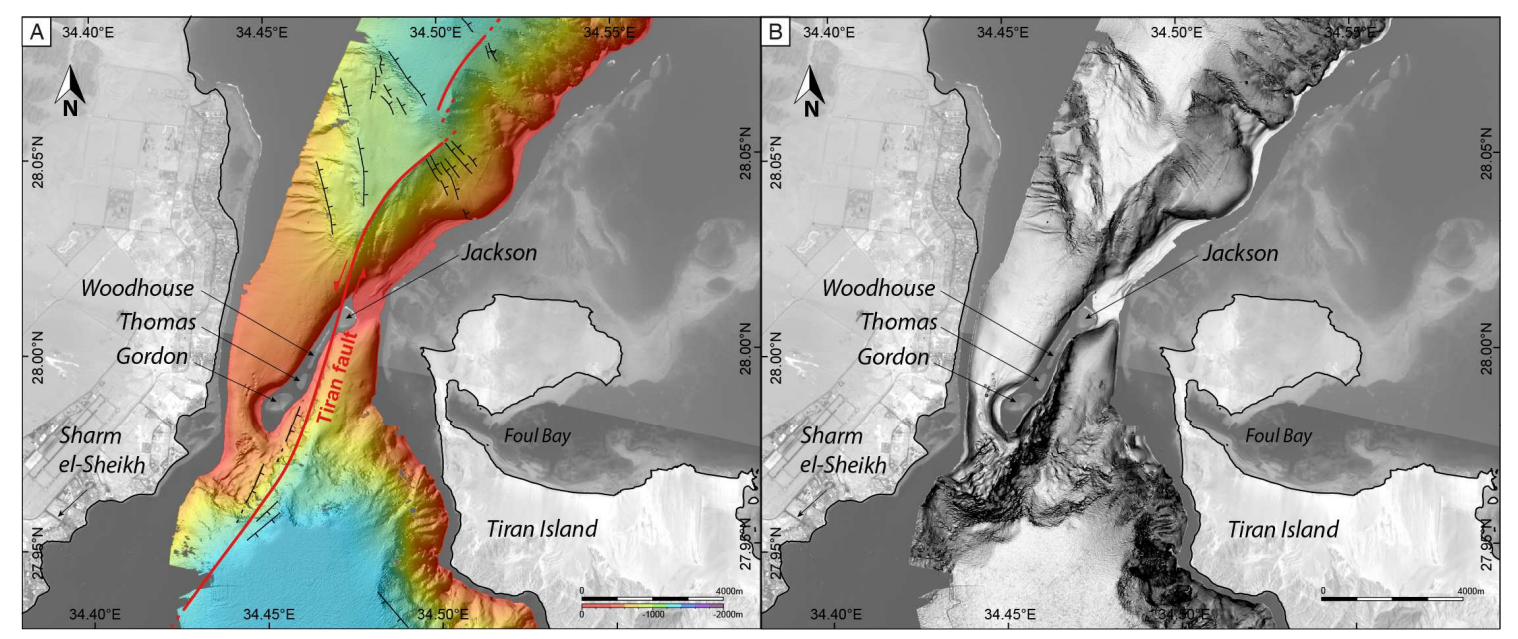

Figure 6: Strait of Tiran (see location on Figure 2). (A) The sinistral strike-slip Tiran Fault is located between the Woodhouse and Jackson reefs. The sharp bathymetry to the North and to the South of the reef emphasizes the location of the fault. Red lines represent the main strikeslip faults, black lines represent the main normal faults. (B) Slope map of the Strait of Tiran, from low slope angle (white: $0^{\circ}$ ) to high slope angle (black: $>45^{\circ}$ ).

\section{Discussion}

\subsection{The 1995, $M_{w} 7.3$, Nuweiba earthquake surface rupture:}

Between the Aragonese and Eilat Deeps, the Aragonese fault (Figure 4A) is characterized by evidence of recent deformation. Along its central section, small basins and counter-slope scarps are visible in the bathymetry, which affect the most recent sediments (Figure $4 \mathbf{B}$ ). Indeed, these geomorphic features are too large to correspond to only one event, for instance the 1995, Mw7.3 Nuweiba earthquake. However, the sharpness of the morphology, compared to any other locations along the strike-slip faults in the GA, advocates for recent rejuvenation

This article is protected by copyright. All rights reserved. 
of that fault section, possibly during the 1995 Nuweiba earthquake. In contrast, although sharp morphology supports long-term normal activity of the Haql fault farther North, the convex profiles of the alluvial fans crossing the fault and the absence of clear scarps crosscutting the active fan surfaces suggest that no recent rupture occurred along that section of the fault. Similarly, no continuity of a potential surface rupture could be identified at the bottom of the Arnona Deep, which marks the end of the Aragonese fault to the South.

Based on geophysical data, two classes of models have been proposed for the source model of the $1995, \mathrm{M}_{\mathrm{w}} 7.3$ Nuweiba earthquake: a single source event, or a series of cascading subevents (Klinger et al., 1999; Shamir et al., 2003; Baer et al., 2008). To be consistent with earthquake scaling laws (Wesnousky, 2008), the single source models need to have a longer rupture and/or larger co-seismic slip than individual sources included into a multi-sources model. Based on the new data presented here, the length of the uninterrupted sharp morphology along the central Aragonese fault is limited to $53 \mathrm{~km}$. Thus, based on scaling laws, a seismic rupture that would be limited to that rupture length only would have a maximum magnitude of Mw7.1, which is not consistent with the magnitude derived from seismological data. Hence, we suggest that our observation advocate for a multi-source earthquake model. The Aragonese fault, indeed, hosted the main sub-event, while an earlier sub-event occurred along the Arnona fault, and a last sub-event occurred on the Eilat fault, as suggested by seismological data as well as dynamic rupture modeling (Klinger et al., 1999; Ulrich et al., 2020). These additional ruptures, however, are smaller and cannot be identified unambiguously in our multibeam bathymetry, calling for further bathymetric investigations at higher resolution in the GA.

\subsection{Earthquake potential along the Arnona Fault}

The Arnona fault, located in the southern part of the gulf, extends from the Aragonese Deep to the Tiran Deep. The structure is linear for $64 \mathrm{~km}$ along the eastern edge of the Dahab plateau, partly buried under shallow salt deposits flowing downward from the plateau into the basins (Figure 1 \& 5). To its northern end, between the Aragonese and Dakar Deeps, the fault azimuth changes from $\mathrm{N} 20$ to $\mathrm{N} 35$, leading to the formation of a relay fault zone with multiple parallel fault strands involving both strike-slip and dip-slip (Figure 4C). None of the fault discontinuities, however, is large enough that it might hinder earthquake rupture propagation (Wesnousky, 2006). Thus, the extent of a possible full-length rupture along the Arnona fault should also include the $18.5 \mathrm{~km}$ that correspond to the Arnona fault section in the Aragonese Deep. Historical records along the DSF have revealed evidence for several large earthquakes that likely occurred in the GA during the past 3000 years (e.g., $4^{\text {th }}$ century

This article is protected by copyright. All rights reserved. 
BC, AD 363, $8^{\text {th }}$ century, AD 1068, AD 1212, and AD 1588 (Ambraseys, 2009)). The temporal organization of large events along active faults (Schlagenhauf et al., 2011; Lefevre et al., 2018), suggests that earthquakes might occur in clusters during short seismically active periods. Along the DSF, the clusters seem to last about 100 yrs to 200 yrs, separated by longer quiescent seismic periods lasting 350 yrs to 400 yrs (Klinger et al., 2015; Lefevre et al., 2018). In the GA, the time gap between the last earthquake, in 1995, and the previous earthquake in $\mathrm{AD} 1588$ conforms to this scheme and it suggests that the DSF might be ripe for a new earthquake sequence with the 1995 Nuweiba earthquake as a starter. Both extremities of the 1995 rupture were brought closer to failure by the 1995 event, and sustained micro-seismicity is observed in the GA (e.g., 2016 sequence (Abd el-aal et al., 2018)). To the South, along the Arnona fault section, our current knowledge does not allow to determine whether the last significant rupture at this location happened in AD 1212 or in AD 1588 (Bektas et al., 2019). Thus, considering a slip-rate along the DSF of $\sim 5 \mathrm{~mm} / \mathrm{yr}$ (Le Béon et al., 2008, 2012), the accumulated slip deficit along the 83-km-long Arnona fault stands between 2 $\mathrm{m}$ and $4 \mathrm{~m}$, which corresponds to a potential earthquake of magnitude comprised between 7.2 and 7.5.

\subsection{The Gulf of Aqaba as a series of pull-apart basins}

Beyond the detail of the activity for the different faults in the GA, the entire fault system that forms the GA illustrates how transtensional fault systems might evolve through time, including by forming multiple imbricated pull-apart basins. The left-lateral DSF along most of its length follows a small circle path, resulting into almost pure strike-slip motion, with two notable exceptions, the Dead Sea pull-apart basin, and the Lebanese restraining bend. At its southern end, however, the small circle geometry is less sustainable as the DSF geometry is also under the influence of the nearby Red Sea spreading center, which connects to the DSF at the triple junction between the GA, the Gulf of Suez, and the Red Sea (Courtillot et al., 1987). Although discussing detail of such junction and its time evolution is beyond the scope of this paper, our bathymetric data emphasize how the departure from a simple small circle geometry leads to the transtensional regime controlling the fault geometry into the gulf, with a large number of normal faults in addition to the strike-slip. The normal evolution of such system should have been toward a simplification of the fault geometry with time (Mann et al., 1983; Stirling et al., 1996) and the localization of the tectonic activity on the main fault (Marco, 2007). It is likely, however, that the reorganization of the regional tectonics about 5 millions years ago, with a change in the position of the pole of rotation of the Arabia plate relative to

This article is protected by copyright. All rights reserved. 
the Sinai microplate (Garfunkel, 1981; Le Pichon and Gaulier, 1988), has increased the extensional component of motion at the southern extremity of the DSF, counteracting the fault simplification process and reactivating normal motion on the numerous faults in and around the GA, largely inherited from an early deformation episode presiding at the emplacement of the DSF (Wu et al., 2009).

\section{Conclusions}

Detailed mapping of active tectonic structures in the GA reveals that the deformation is strongly partitioned between faults accommodating strike-slip motion and extension oblique to the gulf. The two groups of faults are largely parallel, and aligned with the dominant direction of the gulf. In addition, a third group of faults includes shorter normal faults, usually located at extremities of basins, and oblique to the general direction of the gulf. The length of the strike-slip faults identified in our bathymetric map demonstrates the potential for large strike-slip earthquakes, such as the $1995, \mathrm{M}_{\mathrm{w}} 7.3$ Nuweiba earthquake, especially in the southern part of the gulf. The normal faults are more discontinuous and thus, the potential for large normal-fault events is lower, although earthquakes of magnitude up to $\mathrm{M}_{\mathrm{w}} 7$ cannot be ruled out. Such normal fault earthquakes, even of moderate magnitude could potentially trigger devastating tsunami into the gulf. Similarly, although strike-slip earthquakes are less prone to directly trigger major tsunamis, a moderate dip-slip component associated to a large strike-slip motion could also produce significant tsunami (Ulrich et al., 2019). In addition, the bathymetry has revealed the existence of several large submarine alluvial fans in the gulf, with slopes that could be destabilized during either strong strike-slip or normal faulting events and trigger significant tsunami (Goodman-tchernov et al., 2016; Frucht et al., 2019). The absence of large earthquakes and the general seismic quiescence during the last centuries along most of the Dead Sea fault system, including the GA, might give a false sense of security. The 1995, Mw7.3, Nuweiba earthquake, however, should remind the scientific community, as well as civil society and local communities, of the need of a better assessment of the seismic and tsunami hazards in the region of the GA. In particular, additional deep coring throughout the GA to date and locate past earthquakes in the gulf are in need, to complement the 2000 years long seismic record already available farther north along the onshore sections of the DSF.

\section{Acknowledgements}

This article is protected by copyright. All rights reserved. 
This study was funded by King Abdullah University of Science and Technology (KAUST), under award number OSR-2016-CRG6-3027-01. We thank F. Leclerc, an anonymous reviewer, and the editor L. Jolivet for their thorough reviews and useful suggestions that improved this manuscript. We thank Brian C. Hession (CMOR, KAUST) for the help with the multibeam data acquisition and initial processing, and the crew on R/V Thuwal for their work during the May-June 2018 research cruise. Bathymetric data are available from https://doi.org/10.5281/zenodo.4607639.

\section{References}

Abd el-aal, A. el aziz K., Mostafa, S., and Hafiez, H.E.A., 2018, Review of the Seismotectonic Setting of the Gulf of Aqaba with Respect to the 27 June 2015 and the 16 May 2016 Earthquake Sequences: Pure and applied geophysics, v. 176, p. 541-562, doi:10.1007/s00024-018-2024-5.

Abdel-Fattah, A.K., Hussein, H.M., Ibrahim, E.M., and Abu El Atta, A.S., 1997, Fault plane solutions of the 1993 and 1995 Gulf of Aqaba earthquakes and their tectonic implications: annali di geofisica, v. XL, p. 1555-1564.

Al-Arifi, N.S., Lashin, A.A., and Al-Humidan, S., 2012, Migration of local earthquakes in the Gulf of Aqaba, North Red Sea: Earth Sciences Research Journal, v. 16, p. 35-40.

Almadani, S., 2017, Source parameters of the 27th of June 2015 Gulf of Aqaba earthquake: Journal of Seismology, v. 21, p. 1055-1066, doi:10.1007/s10950-017-9651-7.

Ambraseys, N., 2009, Earthquakes in the Mediterranean and Middle East: A Multidisciplinary Study of Seismicity up to 1900: Cambridge, Cambridge University Press, doi:DOI: 10.1017/CBO9781139195430.

Baer, G., Funning, G.J., Shamir, G., and Wright, T.J., 2008, The 1995 November 22 , M w 7 . 2 Gulf of Elat earthquake cycle revisited: , p. 1040-1054, doi:10.1111/j.1365246X.2008.03901.x.

Bektas, Z., Avsar, U., Jónsson, S., and Klinger, Y., 2019, Seismoturbidites in the Gulf of Aqaba during the past 500 years, in EGU General Assembly, v. 21, p. 14681.

Ben-Avraham, Z., 1985, Structural framework of the Gulf of Elat (AQABA), Northern Red Sea: Journal of Geophysical Research, v. 90, p. 703-726, doi:10.1029/JB090iB01p00703.

Ben-Avraham, Z., Almagor, G., and Garfunkel, Z., 1979, Sediments and structure of the Gulf of Elat (Aqaba)-Northern Red Sea: Sedimentary Geology, v. 23, p. 239-267,

This article is protected by copyright. All rights reserved. 
doi:10.1016/0037-0738(79)90016-2.

Le Béon, M., Klinger, Y., Al-Qaryouti, M., Mériaux, A.S., Finkel, R.C., Elias, A., Mayyas, O., Ryerson, F.J., and Tapponnier, P., 2010, Early holocene and late pleistocene slip rates of the southern dead sea fault determined from10Be cosmogenic dating of offset alluvial deposits: Journal of Geophysical Research: Solid Earth, v. 115, p. 1-24, doi:10.1029/2009JB007198.

Le Béon, M., Klinger, Y., Amrat, A.Q., Agnon, A., Dorbath, L., Baer, G., Ruegg, J.C., Charade, O., and Mayyas, O., 2008, Slip rate and locking depth from GPS profiles across the southern Dead Sea Transform: Journal of Geophysical Research: Solid Earth, v. 113, p. 1-19, doi:10.1029/2007JB005280.

Le Béon, M., Klinger, Y., Mériaux, A.S., Al-Qaryouti, M., Finkel, R.C., Mayyas, O., and Tapponnier, P., 2012, Quaternary morphotectonic mapping of the Wadi Araba and implications for the tectonic activity of the southern Dead Sea fault: Tectonics, v. 31, p. 1-25, doi:10.1029/2012TC003112.

Courtillot, V., Armijo, R., and Tapponnier, P., 1987, The Sinai triple junction revisited: Tectonophysics, v. 141, p. 181-190, doi:10.1016/0040-1951(87)90184-3.

Ehrhardt, A., Hübscher, C., Ben-Avraham, Z., and Gajewski, D., 2005, Seismic study of pullapart-induced sedimentation and deformation in the Northern Gulf of Aqaba (Elat): Tectonophysics, v. 396, p. 59-79, doi:10.1016/j.tecto.2004.10.011.

El-Isa, Z.H., Merghelani, H.M., and Bazzari, M.A., 1984, The Gulf of Aqaba earthquake swarn of 1983: Geophysical Journal of the Royal Astronomical Society, v. 78, p. 711721.

Fossen, H., Teyssier, C., and Whitney, D.L., 2013, Transtensional folding: Journal of Structural Geology, v. 56, p. 89-102.

Frucht, E., Salamon, A., Gal, E., Ginat, H., Grigorovitch, M., Tov, R.S., and Ward, S., 2019, A Fresh View of the Tsunami Generated by the Dead Sea Transform, 1995 M w 7.2 Nuweiba Earthquake, along the Gulf of Elat - Aqaba: Seismological Research Letters, v. 90, p. 1483-1493, doi:10.1785/0220190004.

Garfunkel, Z., 1981, Internal structure of the Dead Sea leaky transform (rift) in relation to plate kinematics: Tectonophysics, v. 80, p. 81-108, doi:10.1016/0040-1951(81)90143-8.

Goodman-tchernov, B., Katz, T., Shaked, Y., Qupty, N., Kanari, M., Niemi, T.M., and Agnon, A., 2016, Offshore Evidence for an Undocumented Tsunami Event in the 'Low Risk' Gulf of: PLOS one, p. 1-14, doi:10.1371/journal.pone.0145802.

Hall, J.., and Ben Avraham, Z., 1978, New Bathymetric map of the Gulf of Elat (Aqaba):

This article is protected by copyright. All rights reserved. 
Paper presented at the tenth Int. Congr. Sedimentol. Int. Assoc. Sedimentol, v. I, p. 285, http://ci.nii.ac.jp/naid/10017311531/en/.

Hartman, G., Niemi, T.M., Tibor, G., Ben-avraham, Z., Al-zoubi, A., Makovsky, Y., Akawwi, E., Abueladas, A., and Al-ruzouq, R., 2014, Quaternary tectonic evolution of the Northern Gulf of Elat/Aqaba along the Dead Sea Transform: Journal of Geophysical Research: Solid Earth, p. 1-23, doi:10.1002/2013JB010879.Received.

Hofstetter, A., Thio, H.K., and Shamir, G., 2003, Source mechanism of the 22 / 11 / 1995 Gulf of Aqaba earthquake and its: Journal of Seismology, v. 7, p. 99-114, doi:10.1023/A:1021206930730.

Hussein, H.M., and Abou Elenean, K.M., 2008, Source parameters of the significant earthquakes in Egypt, 1992-1998 inferred from the P-waves magnitude spectra of teleseismic seismograms: Geofizika, v. 25, p. 1-26.

Klinger, Y., Avouac, J.-P., Karaki, N.A., Dorbath, L., Bourles, D., and Reyss, J.L., 2000, Slip rate on the Dead Sea transform fault in northern Araba valley (Jordan): Geophysical Journal International, v. 142, p. 755-768, doi:10.1046/j.1365-246X.2000.00165.X.

Klinger, Y., Le Béon, M., and Al-Qaryouti, M., 2015, 5000 yr of paleoseismicity along the southern Dead Sea fault: Geophysical Journal International, v. 202, p. 313-327, doi:10.1093/gji/ggv134.

Klinger, Y., Rivera, L., Haessler, H., and Maurin, J.-C., 1999, Active Faulting in the Gulf of Aqaba: New Knowledge from the Mw=7.3 Earthquake of 22 November 1995: Bull. Seismol. Soc. Am., v. 89 (4)., p. 1025-1036.

Lefevre, M., Klinger, Y., Al-Qaryouti, M., Le Béon, M., and Moumani, K., 2018, Slip deficit and temporal clustering along the Dead Sea fault from paleoseismological investigations: Scientific Reports, v. 8, p. 1-9, doi:10.1038/s41598-018-22627-9.

Mann, P., Hempton, M.R., Bradley, D.C., and Burke, K., 1983, Development of Pull-Apart Basins: Journal of Geology, v. 91, p. 529-554.

Marco, S., 2007, Temporal variation in the geometry of a strike-slip fault zone: Examples from the Dead Sea Transform: Tectonophysics, v. 445, p. 186-199, doi:10.1016/j.tecto.2007.08.014.

Marco, S., Stein, M., Agnon, A., and Ron, H., 1996, Long-term earthquake clustering: A 50,000-year paleoseismic record in the Dead Sea Graben: Journal of Geophysical Research: Solid Earth, v. 101, p. 6179-6191, doi:10.1029/95jb01587.

Mostafa, S., Hafiez, H.E.A., Abd el-aal, A. el aziz K., Mostafa, S., Hafiez, H.E.A., and Geophysics, A., 2018, Review of the Seismotectonic Setting of the Gulf of Aqaba with

This article is protected by copyright. All rights reserved. 
Respect to the 27 June 2015 and the 16 May 2016 Earthquake Sequences: Pure and applied geophysics, v. 176, p. 541-562, doi:10.1007/s00024-018-2024-5.

Le Pichon, X. t, and Gaulier, J.-M., 1988, The rotation of Arabia and the Levant fault system: Tectonophysics, v. 153, p. 271-294.

Pinar, A., and Türkelli, N., 1997, Source inversion of the 1993 and 1995 Gulf of Aqaba earthquakes: Tectonophysics, v. 283, p. 279-288, doi:10.1016/S0040-1951(97)00070-X.

Reches, Z.E.E. V, 1987, Sedimentary and tectonic features in the northwestern Gulf of Elat, Israel: v. 141, p. 169-180.

Reilinger, R. et al., 2006, GPS constraints on continental deformation in the Africa-ArabiaEurasia continental collision zone and implications for the dynamics of plate interactions: Journal of Geophysical Research: Solid Earth, v. 111, p. 1-26, doi:10.1029/2005JB004051.

Sade, A.R., Hall, J.K., Tibor, G., Niemi, T.M., Ben-Avraham, Z., Al-Zoubi, A.A., Hartman, G., Akawwi, E., Abueladas, A.-R., and Amit, G., 2009, The Multinational Bathymetric Survey: Northern Gulf of 'Aqaba/Elat Poster: Israel Journal of Earth Sciences, v. 57, p. 139-144, doi:10.1560/IJES.57.2.139.

Schlagenhauf, A., Manighetti, I., Benedetti, L., Gaudemer, Y., Finkel, R., Malavieille, J., and Pou, K., 2011, Earthquake supercycles in Central Italy, inferred from 36Cl exposure dating: Earth and Planetary Science Letters, v. 307, p. 487-500, doi:10.1016/j.epsl.2011.05.022.

Shaked, Y., Agnon, A., Lazar, B., Marco, S., Avner, U., and Stein, M., 2004, Large earthquakes kill coral reefs at the north-west Gulf af Aqaba: Terra Nova, v. 16, p. 133138, doi:10.1111/j.1365-3121.2004.00541.x.

Shamir, G., Baer, G., and Hofstetter, A., 2003, Three-dimensional elastic earthquake modelling based on integrated seismological and InSAR data: $\mathrm{Mw}=7.2$ Nuweiba earthquake, gulf of Elat/Aqaba 1995 November: Geophysical Journal International, v. 154, p. 731-744, doi:10.1046/j.1365-246X.2003.01978.x.

Stirling, M.W., Wesnousky, S.G., and Shimazaki, K., 1996, Fault trace complexity, cumulative slip, and the shape of the magnitude-frequency distribution for strike-slip faults: A global survey: Geophysical Journal International, v. 124, p. 833-868, doi:10.1111/j.1365-246X.1996.tb05641.x.

Al Tarazi, E., Abu Rajab, J., Gomez, F., Cochran, W., Jaafar, R., and Ferry, M., 2011, GPS measurements of near-field deformation along the southern Dead Sea Fault System: Geochemistry, Geophysics, Geosystems, v. 12, doi:10.1029/2011GC003736.

This article is protected by copyright. All rights reserved. 
Thomas, R., Parker, S.T., and Niemi, T.M., 2007, Structural Damage from Earthquakes in the Second - Ninth Century at the Archaeological Site of Aila in Aqaba, Jordan: Basor, v. 346 , p. 59-77.

Tibor, G., Niemi, T.M., Ben-Avraham, Z., Al-Zoubi, A., Sade, R.A., Hall, J.K., Hartman, G., Akawi, E., Abueladas, A., and Al-Ruzouq, R., 2010, Active tectonic morphology and submarine deformation of the northern Gulf of Eilat/Aqaba from analyses of multibeam data: Geo-Marine Letters, v. 30, p. 561-573, doi:10.1007/s00367-010-0194-y.

Tubbs, R.E., Hussein G, A.F., Afifi, A.M., Raterman, N.S., Hughes, G.W., and Fadolalkarem, Y.K., 2014, Midyan Peninsula, northern Red Sea, Saudi Arabia: Seismic imaging and regional interpretation: GeoArabia, v. 19, p. 165-184.

Ulrich, T., Gabriel, A.-A., Klinger, Y., and Ampuero, J.-P., 2020, Exploring the dynamics of the Dead-Sea Transform fault using data-integrated numerical models, in AGU Fall Meeting 2020,.

Ulrich, T., Vater, S., Madden, E.H., Behrens, J., van Dinther, Y., van Zelst, I., Fielding, E.J., Liang, C., and Gabriel, A.A., 2019, Coupled, Physics-Based Modeling Reveals Earthquake Displacements are Critical to the 2018 Palu, Sulawesi Tsunami: Pure and Applied Geophysics, v. 176, p. 4069-4109, doi:10.1007/s00024-019-02290-5.

Wechsler, N., Rockwell, T.K., and Klinger, Y., 2018, Variable slip-rate and slip-per-event on a plate boundary fault: The Dead Sea fault in northern Israel: Tectonophysics, v. 722, p. 210-226, doi:10.1016/j.tecto.2017.10.017.

Wesnousky, S.G., 2008, Displacement and geometrical characteristics of earthquake surface ruptures: Issues and implications for seismic-hazard analysis and the process of earthquake rupture: Bulletin of the Seismological Society of America, v. 98, p. 16091632, doi:10.1785/0120070111.

Wesnousky, S.G., 2006, Predicting the endpoints of earthquake ruptures: Nature, v. 444, p. 358-360, doi:10.1038/nature05275.

Wu, J.E., Mcclay, K., Whitehouse, P., and Dooley, T., 2009, 4D analogue modelling of transtensional pull-apart basins: Marine and Petroleum Geology, v. 26, p. 1608-1623, doi:10.1016/j.marpetgeo.2008.06.007.

This article is protected by copyright. All rights reserved. 